\title{
Transatlantiniai santykiai ir Lietuva: dar kartą apie saugumą
}

Šiame straipsnyje aptariama pastaraisiais metais viešojoje erdveje dažnai diskutuojama sumažejusio JAV dèmesio Lietuvai ir apskritai Vidurio ir Rytų Europos (VRE) regionui problema, nagrinejjama kintanti tarptautine aplinka, JAV „posūkis ị Aziją“ ir galimi JAV užsienio politikos pokyčiai antrosios Prezidento Baracko Obamos kadencijos metu. Šie veiksniai gali turèti ir tam tikrą poveikị Lietuvai - straipsnyje pateikiami argumentai, kad pasiekta narystė NATO Lietuvai nereiškia jos saugumo klausimų sprendimo ir transatlantinių santykių plètojimo pabaigos. Tyrimai rodo, kad net ir praejjus narystės euroatlantinėse struktūrose dešimtmečiui, Lietuva dar nèra iki galo integravusis ị transatlantinę saugumo bendruomenę. NATO pastaraisiais metais susiduria ne tik su globaliomis XXI amžiaus grèsmèmis, bet ir paaštrejjusia išlaidų pasidalijimo problema. Lietuvos saugumo situacija dèl Aljanso teikiamos kolektyvinès gynybos garantijų vertinama kaip geriausia nuo nepriklausomybès atkūrimo, tačiau tai neatleidžia nuo būtinybès pačiai plètoti savo gynybinius pajègumus. Remiantis mažos valstybès ir neoklasikinio realizmo teorine perspektyva, straipsnyje aptariami valstybės užsienio politiką paaiškinantys išorès ir vidaus veiksniai, analizuojamos Lietuvos elgsenos tarptautineje erdvèje, tarp jų ir Šiaurès Atlanto Aljanse, galimybès. Straipsnyje analizuojamos galimybès Lietuvai, kaip vienai iš Europos Sąungos valstybių, prisideti prie bendro Europos požiūrio ị JAV suformavimo ir naujų galimybių transatlantinès partnerystès plètojimui atverimo.

\section{Ivadas}

Viešojoje erdveje pastaraisiais metais vis pasigirsdavo nuomonių apie sumažėjusį JAV dėmesį Vidurio ir Rytų Europos regionui (toliau - VRE), taigi, ir Lietuvai, ${ }^{1}$ ir apie galimą jo poveikị šalių saugumui. Šiuos nuogąstavimus išprovokavo pasikeitę JAV planai dèl priešraketinès gynybos sistemos Rytų Europoje ir prielaida, kad pasikeitus JAV politikai Rusijos atžvilgiu ,itraukimui“ (ang. engagement) pakeitus „sulaikymą“ (ang. deterrence) ir taikant „švelniąją

\footnotetext{
* Sigita Trainauskienè - Kauno technologijos iniversiteto Socialinių mokslų fakulteto doktorantè. Adresas korespondencijai: K. Donelaičio g. 20-508, 44239 Kaunas, tel. (8-37) 3001 44, el. p. sockat@ktu.lt. ${ }^{1}$ Pvz., "An Open Letter to the Obama Administration from Central and Eastern Europe," RFE/RL, July 16, 2009; Bugajski J., „Unintended Consequences: Impact Of The U.S. - Russia Détente On The Wider Europe “, Lithuanian Foreign Policy Review 24, 2010, p. 9-22; Lopata R., „The Lithuanian-American Association: Why Do We Need the US?“, Lithuanian Foreign Policy Review 23, 2010, p. 111-112.
} 
galią“ stiprès ekspansinès nuotaikos Rusijoje, todèl jos kaimynès galimai taps labiau pažeidžiamos. Kita vertus, yra ir nuomonių, kad Baltijos jūros rytinio regiono susirūpinimas dèl Vašingtono įsipareigojimo šio regiono šalių saugumui užtikrinti tvirtumo yra nepagrịstas, o VRE valstybès „turètų paremti JAV siekị atkurti santykius su Rusija, nors sèkmè nèra garantuota“2.

Ši diskusija liudija, kad saugumo problemos regione išlieka aktualios, nepaisant to, kad Lietuva, kaip ir kitos regiono valstybès, jau beveik dešimtmeti yra NATO - nuolat kolektyvinei gynybai issipareigojusio („24 valandas per parą, 7 dienas per savaitę, 365 dienas per metus ${ }^{\text {“3) }}$ ) Aljanso narès. Viena vertus, pripažįstama, kad dabartinė Lietuvos padėtis tarptautineje saugumo sistemoje yra geriausia nuo nepriklausomybès atkūrimo, kita vertus, Lietuvos Respublikos Nacionalinejje saugumo strategijoje identifikuojami tam tikri išorès ir vidaus rizikos veiksniai ir grèsmès nacionaliniam saugumui (pastaraisiais metais ypač akcentuota energetinio saugumo problema), tebekalbama apie būtinybę sèkmingai įsitvirtinti euroatlantinèse struktūrose ${ }^{4}$, toliau stiprinti transatlantinị ryšį; tebesitęsia akademinė diskusija apie užsienio politikos „saugumizavimo“ tendencijas, pvz., klausimuose su Rusija ${ }^{5}$.

Lietuvos rūpinimasis nacionaliniu saugumu ir transatlantine partneryste, žvelgiant iš mažos valstybès perspektyvos ir turint galvoje istorinę patirtį, visiškai suprantamas. Lietuvos politinis, akademinis elitas iš esmès vieningai pripažįsta išskirtinị JAV vaidmenį atkuriant nepriklausomą Lietuvos valstybę ir tebelaiko ją „pagrindine Lietuvos saviveiksmiškumo garantija“6. Lietuvos ir JAV santykiai apibūdinami kaip strateginè partneryste $\dot{e}^{7}$, kurią lemia idejjinès, geopolitinès, politinès aplinkybès, todèl JAV užsienio politikos pokyčiams Lietuva yra itin jautri. JAV ir Lietuvos santykius analizavę Vaidotas Urbelis ir Gerda Jakštaitė atkreipė dèmesị, kad Lietuvos, kaip mažos valstybès reikšmingumas JAV

\footnotetext{
${ }^{2}$ Krickus D., „Barack Obama ir saugumas Baltijos jūros rytiniame regione“, Lietuvos metine strategine apžvalga, 2010-2011, p. 9.

${ }^{3}$ Secretary General welcomes Lithuanian leadership and commitment, February 1, 2013, http://www.nato. int/cps/en/SID-D047024D-A5B7A679/natolive/news_94378.htm, 01022013.

${ }^{4}$ Lietuvos Nacionalinio saugumo strategija, 2012, XIP-3399(2), XV-osios LR Vyriausybès programa, 2008, XI-52.

${ }^{5}$ Pvz., Statkus N., Paulauskas K., Tarp geopolitikos ir postmoderno: kur link sukti Lietuvos užsienio politikai, Vilnius, 2008; taip pat T. Janeliūno, G. Miniotaitès ir kt. darbai. Apie RF spec. tarnybų veiklą Lietuvoje žr. VSD $2012 \mathrm{~m}$. veiklos ataskaita visuomenei.

${ }^{6}$ Lopata R., „Kodèl mums, lietuviams, reikalinga Amerika?““, http://www.bavi.lt/r-lopata-kodel-mums-lietuviams-reikalinga-amerika/, 12092012.

${ }^{7}$ Žr. plačiau- XV-osios LR Vyriausybès programa, 2008; Lietuvos Nacionalinio saugumo strategija, 2012 , XIP-3399(2).
} 
požiūriu pasireiškia tik regiono - VRE ar Šiaurès-Baltijos - kontekste ${ }^{8}$. Kaip atsvaros „perkrovos“ politikai, VRE šalys pastaraisiais metais sieke patikinimo (ang. reassurance), kad JAV išlieka ịsipareigojusios regiono saugumui, arba, kaip Lenkija, mégino pačios „perkrauti“ (ang. reset) savo santykius su Rusija. Visgi, analitikų nuomone, VRE regiono valstybes veikè ne tiek „naujosios Jaltos“ baimè ar abejonès NATO politine valia, kiek pasigesta aiškios JAV politikos šiame regione vizijos ${ }^{9}$, kaip regiono šalių užsienio politiką struktūruojančio veiksnio.

Kita vertus, pačioje Lietuvoje, pasiekus istoriniais laimẻjimais laikomą Lietuvos narystę NATO ir ES, pastebimas tam tikras užsienio politikos idejju vakuumas, kurị mėginta užpildyti ịvairiu turiniu. Bene aiškiausias bandymas apibrežti pointegracinę naująją užsienio politikos koncepciją buvo dar 2004 metų laikinojo Respublikos Prezidento Artūro Paulausko kalba Vilniaus universitete $^{10}$. Tačiau tai buvo, veikiau, diskusijų pradžia, o ne pabaiga. Evaldo Nekrašo teigimu, išnykus tiesioginei egzistencinei grèsmei Lietuvos valstybei, derèjo tokią pačią svarbą teikti valstybès ir piliečių gerovès klausimams ${ }^{11}$, rinktis Vakarų, o ne Rytų politiką. Nortautas Statkus ir Kęstutis Paulauskas ragino persvarstyti Lietuvos euroatlantizmo politiką, kuri „neturètų būti šalies užsienio politikos dogma ${ }^{\text {"12 }}$, Česlovas Laurinavičius ir kt. kvietė pereiti prie „normalaus balansavimo Lietuvos kolektyvinių ịsipareigojimų ribose ${ }^{\text {“13 }}$, arba, pasak Raimundo Lopatos, suvokti „ir NATO, ir ES“ paradigmą kaip „permanentinį dviejų lojalumų sprendimą, kurio kriterijus - ne formalus, bet tikras išèjimas iš Rytų ittakos sferos ${ }^{\text {“14 }}$. Lietuvos, kaip regiono lyderès koncepcijai mèginta priešpastatyti auksinès Europos provincijos koncepciją ${ }^{15}$, atgaivinti geros kaimynystės idejjas ${ }^{16}$, bet apskritai pasigendama aiškesnès Lietuvos užsienio politikos vizijos ${ }^{17}$.

\footnotetext{
${ }^{8}$ Žr. plačiau - Urbelis V., Lietuvos vieta JAV didžiojoje strategijoje, Vilnius, 2005; taip pat Jakštaitè G., Rusijos sulaikymo ir ịtraukimo strategijos šiuolaikinejje JAV užsienio politikoje ir Baltijos šalių reikšmingumas, VDU, 2012.

${ }^{9}$ Larrabee F. S., Chivvis, Ch. S., „Biden“s Task in Eastern Europe: Reassurance“, RAND, 18122012

${ }^{10}$ Laikinojo Prezidento A. Paulausko kalba Vilniaus universitete „Naujoji Lietuvos užsienio politika“, http://paulauskas.president.lt/one.phtml?id=4994, 12092012.

${ }^{11}$ Nekrašas E., "Kritiniai pamąstymai apie Lietuvos užsienio politiką“, Politologija, 2 (54), 2009, p. 127;

${ }^{12}$ Statkus N., K. Paulauskas K., ,Lietuvos užsienio politika tarptautinių santykių teorijų ir praktikos kryžkelejje“, Politologija, 2 (42), 2006, p. 54.

${ }^{13}$ Laurinavičius Č., Lopata R., Sirutavičius V., „Kritinis požiūris ị Lietuvos užsienio politiką: kas pasikeitè nuo Augustino Voldemaro laikų “6, Politologija, 2 (54), 2009, p. 117.

${ }^{14}$ Lopata R., „Debatai dèl Lietuvos užsienio politikos“, Politologija 1 (57), 2010, p. 130.

${ }^{15}$ Taip pat žr. K. Girnius, „Ar esame Europos provincija?“, http://www.delfi.lt/news/ringas/lit/kgirnius-aresame-europos-provincija.d?id=50335636, 12092012.

${ }^{16}$ XVI-osios LR Vyriausybès programa, V.Ž., 2012-12-20, Nr. 149-7630.

${ }^{17}$ Girnius K., ,Prezidentės užsienio politika - važiuoti ar nevažiuoti?““, http://www.delfi.lt/news/ringas/lit/ kgirnius-prezidentes-uzsienio-politika-vaziuoti-ar-nevaziuoti.d?id=58735513, 13092012.
} 
Šiame straipsnyje kviečiama grịžti prie transatlantinių santykių ir teigiama, kad tai - dar neišsemta tiek Lietuvos užsienio politikos, tiek akademiniu diskusijų tema. Transatlantiniai santykiai apskritai reiškia JAV ir Europos ryšį; transatlantinès saugumo bendruomenès sąvoka apima: a) bendrą tapatybę ir vertybes, b) (ekonominę) tarpusavio priklausomybę, c) bendras institucijas, paremtas normomis, reguliuojančiomis šiuos santykius ${ }^{18}$; kitaip tariant, reiškia stipriai integruotą socialinę grupę. Lietuvos patirčiai NATO aptarti skirtoje kolektyvinèje studijoje „Beieškant NATO Lietuvoje ${ }^{\text {“19 }}$ pastebima, kad net ir po beveik dešimtmečio narystès Aljansas dar nèra tapęs mūsų savasties dalimi, o, veikiau, suvokiamas kaip ,jie“, „kiti“. Priešraketinès gynybos istorija, pasak Shapiro ir Witney, atskleidè tikrai gilų pasitikejjimo trūkumą tarp naujųjų NATO ir ES narių šių bendruomenių solidarumu ir kolektyvine stiprybe ${ }^{20}$. Nors JAV ir Europa viena kitai yra svarbiausios prekybos partnerès, pagrindine Lietuvos prekybos partnere vis dar išlieka Rusija - ji yra pirmoje vietoje tiek pagal importo, tiek pagal eksporto apimtị: $2011 \mathrm{~m}$. tai atitinkamai sudaré 32,8 proc. ir 16,6 proc. nuo bendros apimties, didžioji dalis - energetiniai ištekliai ${ }^{21}$. Tuo tarpu JAV nepatenka nei ị svarbiausių prekybos partnerių, nei investuotojų dešimtuką ${ }^{22}$. Lietuva su partneriais užsitikrino NATO Baltijos valstybių gynybos planus, tačiau jos pačios skiriamos išlaidos gynybai sumažèjo iki kritinės ribos - 2012 m. jos siekè vos 0,8 proc. BVP. Apskritai Europa, būdama priklausoma nuo JAV karinès galios, paradoksaliai stokoja bendro europinio požiūrio ị JAV ir transatlantinị ryši (ir kitas augančias galias). Pirmoji Obamos kadencija pasižymëjo ne tik santykių su Rusija „perkrova“, bet ir JAV dèmesio nukreipimu ị kitus regionus, visų pirma, Azijos ir Ramiojo vandenyno regionąa ${ }^{23}$, tai Lietuvos viešajame diskurse kol kas nebuvo plačiau aptarta. Analitikai abiejose Atlanto pusėse svarsto, kaip JAV ir Europa galètų ir toliau

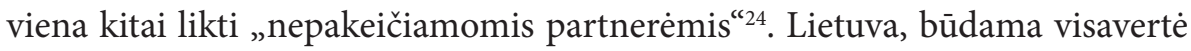

\footnotetext{
${ }^{18}$ Risse T., „Beyond Iraq: The Crisis of the Transatlantic Security Community“, in: Ifantis K. et al, Multilateralism and security institutions in an era of globalization, London: Routledge, 2008, p. 78.

${ }^{19}$ Jakniūnaitė D., Paulauskas K., sudar., Beieškant NATO Lietuvoje, VU TSPMI, 2010.

${ }^{20}$ Shapiro J., Witney N., Towards a Post-American Europe: A Power Audit of EU-US Relations, ECFR, http://pasos.org/wp-content/archive/ECFR_EUUSrelations.pdf, 29122012.

21-Lietuvos užsienio reikalų ministerijos informacija, https://www.urm.lt/index.php?4025573062, 2601 2013.

${ }^{22}$ United States Census Bureau, U.S. International Trade in Goods and Services - Annual Revision for 2011, http://www.census.gov/foreign-trade/Press-Release/2011pr/final_revisions/11final.pdf, 1109 2012; Lietuvos Statistikos departamentas, Tiesioginés užsienio investicijos metu pabaigoje, 18092012.

${ }^{23}$ Manyin M., E., Daggett S., Dolven B., Lawrence S.V., Martin M. F., O‘Rourke R., Vaughn B., Pivot to the Pacific? The Obama Administration's "Rebalancing " Towards Asia, Congressional Research Service, March 28, 2012, http://www.fas.org/sgp/crs/natsec/R42448.pdf, 29122012.

${ }^{24}$ Žr. plačiau, Lagadec E., Transatlantic Relations in the 21st Century: Europe, America and the Rise of the Rest, Routledge, 2012.
} 
euroatlantinės bendruomenès naré $\dot{e}^{25}$, turètų šioje diskusijoje dalyvauti.

Juolab, kad sulig Lietuvos naryste NATO, žymiai sustiprinusia regiono saugumą, kai egzistencinès grèsmès tikimybè vertinama kaip neegzistuojanti ar bent jau minimali, jos saugumo klausimų sprendimas nesibaigè, nes:

- Lietuva, būdama maža valstybè, dèl savo geopolitinès padèties turi nuolat stebèti ir vertinti išorès aplinkos pokyčius ir tinkamai i juos reaguoti;

- Tinkamam saugumo problemų sprendimui reikalingas pagrindinių vidaus veikèjų sutarimas dẻl kylančiu grèsmių pobūdžio ir atsako ị jas suradimo;

- Kolektyvinès gynybos garantijos neatleidžia Lietuvos nuo būtinybès plètoti savo gynybinius pajegumus (ir skirti tam atitinkamą finansavimą);

- atsižvelgiant ị ekonominio-socialinio saugumo aspektus, siektina gilesnè integracija ị transatlantinę saugumo bendruomenę ir šioje srityje, atitinkamų institucijų ir vertybių stiprinimas.

Neorealizmo teorija tarptautinę sistemą apibūdina kaip esančią anarchinio pobūdžio, kur esminis veiksnys - valstybių turima galia, o pagrindinis jų imperatyvas - saugumas. Ši teorija iš esmès paaiškina ilgalaikius tarptautinės politikos rezultatus, tačiau siekiant paaiškinti konkrečius valstybès užsienio politikos pasirinkimus (pvz., „Rytu““ ar „Šiaurès“ kryptis Lietuvos užsienio politikoje po $2004 \mathrm{~m}$.), vien sisteminių veiksnių nepakanka. Todèl šiame straipsnyje bus remiamasi ir neoklasikinio realizmo teorinėmis nuostatomis: mažos valstybès užsienio politiką didele dalimi lemia tarptautinès sistemos struktūriniai veiksniai, valstybės geopolitinė padètis, tačiau išorès aplinkos spaudimas veikia ne tiesiogiai, o per ịsiterpiančius vidaus veiksnius - valstybès struktūrą ir sprendimų priémejjų suvokimą.

\section{Mažoji valstybè tarptautinèje sistemoje: ieškant saugumo}

\subsection{Saugumas}

Tarptautinèse saugumo studijose saugumas paprastai aptariamas galios politikos kontekste ir siejamas su tradicine politine-karine saugumo samprata, kur saugumas iš esmès reiškia išlikimą, arba grèsmès nebuvimą. Pasak Gleno

${ }^{25}$ LR Seimo rezoliucija dèl užsienio politikos krypčių, 2004 m. gegužès 1d. 
Snyderio, saugumas reiškia „stiprų pasitikejjimą, kad vertybės, kurių laikomasi (t. y. teritorinis integralumas, politinè nepriklausomybė ir kt.), bus apsaugotos išorinès karinès grèsmès atveju“" ${ }^{26}$. Keno Bootho požiūriu, saugumas reiškia daugiau nei išlikimą (survival-plus) ${ }^{27}$, t. y. ne tik grèsmès neišgyventi nebuvimą, bet ir tam tikrus gyvenimo pasirinkimus. Saugumo dilema apskritai laikoma pamatine sąvoka saugumo studijose, kadangi, pasak Bootho ir Wheeler'io, ji susijusi su egzistencine netikrumo sąlyga, būdinga visiems santykiams tarp žmonių, ne tik sąveikai pačioje agresyviausioje - tarptautinejje arenoje ${ }^{28}$. Laikoma, jog nè viena vyriausybè ar politikos formuotojai negali būti absoliučiai tikri dẻl kitų veikèjų, galinčių daryti įtaką valstybès saugumui, esamų ir būsimų intencijų ir motyvų („neišsprendžiamas netikrumas“), todèl vertinant galimas grèsmes, tenka būti labai konservatyviems.

Klausimas apie saugumą paprastai suponuoja, kad iškilo grèsmé tam tikro objekto egzistencijai (tradiciškai, bet nebūtinai, valstybès, tautos), kurią kelia kiti tarptautinès sistemos veikejjai (pvz., revizionistinès valstybės), turintys daugiau galios (karinès, ekonominès), esantys geografiškai arti ir turintys priešiškų ketinimų. Kaip teigia Statkus ir Paulauskas, remiantis neorealistine paradigma, valstybės saugus egzistavimas užtikrinamas tada, kai kitos valstybès arba neturi piktavalių ketinimų, arba galios jų igyvendinimui ${ }^{29}$. Valstybių strategija grèsmių akivaizdoje paprastai yra siekti balansavimo (rečiau - prisišliejimo) arba igyti daugiau galios.

Egzistuoja ir kitas požiūris, jog saugumas kyla ne iš gebejimo sutelkti ir panaudoti galią prieš kitus, bet iš bendradarbiaujamo santykio. Vadinamoji Kopenhagos mokykla kvestionuoja objektyvaus saugumo sampratą (išskyrus akivaizdžius ir tiesioginès grèsmès atvejus) ir teigia, jog daugeliu atveju ji yra socialiai sukonstruota ir intersubjektyvi ${ }^{30}$. Literatūroje teigiama, jog saugumas yra savireferentinè (ang. self-referential) praktika, arba būdas, kuriuo tam tikras klausimas tampa saugumo klausimu: jis nebūtinai turi kelti realią egzistencinę grèsmę, kiek kalbėtojo, kaip toks yra pristatomas ir auditorijos suprantamas, kaip grèsmè išlikimui (tapatybei). Kitaip tariant, saugumas nepriklauso nei objektui, nei subjektui, jis egzistuoja tarp subjektų ${ }^{31}$. Buzano ir kt. teigimu, klausimo „saugumizavimas“ perkelia politiką už nusistovejjusių žaidimo taisyklių ribų, pada-

\footnotetext{
${ }^{26}$ Snyder G., Alliance Politics, 1997, Cornell University Press, p. 5.

${ }^{27}$ Booth K., Theory of World Security, Cambridge University Press, 2007, p. 95.

${ }^{28}$ Booth K., Wheeler, N. J. „Uncertainty“, in: Security Studies: An Introduction, P. Williams, ed., 2008, p. 133.

${ }^{29}$ Statkus N., Paulauskas K., Tarp geopolitikos ir postmoderno: kur link sukti Lietuvos užsienio politikai, Vilnius, 2008, p. 22-23.

${ }^{30}$ Žr. plačiau, Wæver, O. "Securitization and Desecuritization" in: Lipschutz R., ed., On Security, New York: Columbia University Press, 1995, p. 46-86.

${ }^{31}$ Buzan B., Weaver O., de Wilde J., Security: A New Framework for Analysis, 1998, p. 31.
} 
rydamas ji „nepaprastosios“ politikos (arba virš politikos esančiu) objektu ${ }^{32}$; iš esmès tampa pateisinamas bet kokių priemonių panaudojimas.

Kriterijai, pagal kuriuos tam tikras klausimas pripažistamas kaip egzistencinès reikšmès, yra šie: kai galima argumentuoti, kad jis yra svarbesnis nei visi kiti ir jam turi būti suteiktas absoliutus prioritetas; kad neišsprendus šio klausimo, visi kiti gali tapti nebesvarbūs; klausimas netelpa ị ịprastinès politikos rèmus. Tačiau demokratinèje valstybèje saugumo klausimai neturi būti suabsoliutinti (pvz., dèl pavojaus juos išnaudoti vidaus politikos tikslais); idealiu atveju politika turi gebèti išsirutulioti remdamosi ịprastinèmis procedūromis, nesigriebiant skubių kraštutinių priemonių. Optimali ilgalaikè strategija - desekuritizacijos strategija, t. y. tam tikrų klausimų sprendimo iš diskurso lauko "grèsmè ir atsakomoji priemonë“ iškèlimas ir perejimas prie ịprastinès viešosios sferos ${ }^{33}$. Maria Mälksoo Baltijos valstybių užsienio politiką yra pavadinusi egzistencialistine, kuri po valstybių integracijos į NATO ir ES, palaipsniui turejjo virsti normalia politika ${ }^{34}$. Šiuolaikiniai saugumo teoretikai linkę pabrèžti abiejų požiūrių sintezę ieškant saugumo problemų sprendimo.

\subsection{Mažoji valstybè}

Mažosios valstybès, prie kurių priskiriama ir Lietuva, yra itin jautrios sprendžiant saugumo klausimus, nes jos turi „ribotą galią ir neturi galimybių daryti esminę ịtaką nusistovẻjusiai pasaulio tvarkai “"35. Akademinèje literatūroje jos pakankamai mažai ištyrinètos, netgi buvo laikomos ignoruojamomis ${ }^{36}$, kadangi, remiantis neorealistine teorija (Waltzas, Carras, Morgenthau, Niebhuras ir kt.), mažųjų valstybių elgseną tarptautineje sistemoje ypač riboja (ir pakankamai gerai paaiškina) struktūriniai veiksniai, priešingai nei didžiųjų valstybių atveju. Mažosios valstybès ịprastai traktuojamos kaip tarptautinių santykių objektas, o ne subjektas, o jų užsienio politika - kaip „prisitaikymas prie realybès“.

Paprastai valstybė priskiriama vienai iš kategorijų - supergalia, didžioji,

\footnotetext{
${ }^{32}$ Ten pat, p. 23.

${ }^{33}$ Ten pat, p. 29.

${ }^{34}$ Mälksoo M., „From Existential Politics Towards Normal Politics? The Baltic States in the Enlarged Europe“, Security Dialogue, September 2006, vol. 37, no 3., pp. 288, http://sdi.sagepub.com, 24022007

${ }^{35}$ Jankauskas A., sudar., Politikos mokslu enciklopedinis žodynas, VU TSPMI, 2007, p. 77.

${ }^{36}$ Žr. plačiau - Handel M., Weak States in the International System, 1990, Frank Cass \& Co Ltd,; Elman M., "The Foreign Policies of Small States: Challenging Neoralism in Its Own Backyard", British Journal of Political Science, Vol. 25, No. 2 (Apr. 1995), pp. 171-217, http://www.jstor.org/stable/194084, 2912 2012.
} 
vidutinè, mažoji galia arba minivalstybe் - remiantis objektyviais, materialiais jos galios parametrais. Pasak Roberto Rothsteino ${ }^{37}$, mažajai valstybei būdingi bruožai yra: 1) ji pripažista, kad negali užsitikrinti saugumo savo pačios turimomis priemonèmis ir todèl turi iš esmès pasikliauti kitų valstybių, institucijų, procesų ar ịvykių raida, 2) jai būdingas nedidelis saugumo koeficientas (ang. "narrow margin of safety“), 3) valstybès vadovai suvokia jos silpnumą kaip iš esmės nepakeičiamą savybę. Mažųų valstybių užsienio politikai priskiriamos tokios būdingos savybės, kaip, siauras užsienio politikos klausimų ratas ir dèmesys artimiausiam geografiniam regionui; tarptautinès teisès, moralès principų akcentavimas; dalyvavimas daugiašalèse ir tarptautinèse institucijose; pasikliovimas supergalia, užsitikrinant apsaugą, partnerystę ir išteklius; itin didelių užsienio politikos išteklių skyrimas, siekiant užsitikrinti saugumą ir išlikimą; lankstumas ir kūrybiškumas. Ne vienas autorius pažymi geografinị (kitur - geopolitinị) veiksnị, kaip pirminị, darantị įtaką mažųjų valstybių užsienio politikai. Minètas veiksnys yra valstybès karinè ir strateginè situacija (nepalankia padètimi laikoma galingesnių šalių, kurių interesai susikerta, kaimynystè), priklausomybè nuo gamtinių išteklių importo ir kt.

Michaelis Handelis vartoja silpnosios valstybès apibrèžimą ${ }^{38}$, kur svarbūs ne tik objektyvūs, bet ir tam tikri „intuityvūs“ kriterijai, kaip pvz., ne tiek šalies dydis, kiek stiprybès (ang. strength) neturèjimas. Pabrèžiama, kad valstybès stiprumas ar silpnumas - tai veikiau santykinis, o ne absoliutus dydis, dinaminé, o ne fiksuota savybè. Jis skiria vidinius tokius, kaip geografinès ir materialinès sąlygos, žmogiškieji ištekliai, organizaciniai gebėjimai (politinès institucijos ir kt.), ir išorinius valstybès stiprybès šaltinius - formalius ir neformalus aljansus. Pastarieji laikomi pirminiu nacionalinès saugumo politikos instrumentu, būdinga mažos valstybès elgsenos tarptautinèje politikoje strategija. Nors pirminè aljanso paskirtis - bendras išorès grèsmių atrèmimas, literatūroje pabrěžiama ir papildomų jo vidinių saitų, kaip tarpusavio prekyba ar bendros vertybès, reikšmè. Stephen M. Walt'as, nagrinèjęs aljansų formavimą, daro išvadą, kad bendri politiniai interesai yra kur kas svaresnis veiksnys už bendrą ideologiją ${ }^{39}$. Pvz., tikimybę valstybei nebūti paliktai užpuolimo atveju didina strateginių išteklių aljanso infrastruktūros buvimas. Augant grèsmei (pvz., kintant galios balansui), racionali valstybės elgsena, anot Glenno H. Snyderio - stiprinti santykius su aljansu, remti sąungininkus, kurti lojalaus, ryžtingo partnerio

\footnotetext{
${ }^{37}$ Rothstein, R., Alliances and Small Powers, Columbia University Press, 1968.

${ }^{38}$ Žr. plačiau, Handel M., Weak States in the International System, 1990, Frank Cass \& Co Ltd, p. 68.

${ }^{39}$ Stephen M. Walt, ,Alliance Formation and the Balance of World Power“", International Security, Vol. 9, No. 4, Spring 1985 , p. 3-43.
} 
reputaciją, pabrèžti abipusę priklausomybę ir ịsipareigojimus ${ }^{40}$. Pasak Handelio, silpnos valstybès niekuomet negali sau leisti prabangos prarasti budrumo saugumo reikaluose ar mègautis vien tik didžiosios galios teikiamu saugumu.

Globaliame pasaulyje valstybès ,švelnioji galia“41 , t. y. komunikaciniai, organizaciniai, instituciniai gebejjimai, tarpusavio priklausomybės išnaudojimas, o ypač gebejjimas tiksliai reaguoti į naują informaciją - minimi kaip reikšmingi veiksniai, kalbant apie ekonominį, socialinį saugumą, valstybės galią Europos Sąungos kontekste (pvz.: inovatyvių idejjų iškèlimas, gebejjimas formuoti darbotvarkę ar diskursą keičiant kitų veikejjų preferencijomis). Vienas iš tokių atvejų, kaip mažoji valstybė gali daryti įtaką tarptautinei sistemai, yra Skandinavijos šalys, ịsitvirtinusios pasaulio bendrijoje kaip tam tikrų normų tarptautinèje politikoje kūrejos.

Neoklasikinio realizmo mokyklai atstovaujantys autoriai (Rose, Schweller, Lobell ir kt.) pabrěžia, kad vieneto lygmens kintamieji tokie, kaip valstybès vidaus struktūra, jos sprendimų prièmejai, „raktiniai“ socialiniai ir ekonominiai veikejai ir konsensuso tarp jų stoka gali tapti kliuvinys racionaliai valstybės elgsenai, kaip daro prielaidą grèsmių balanso teorija. Pirma, galios (ir atskirų jos elementų) pokyčių ir kylančių grèsmių pobūdžio (tiek globalių, tiek regioninio ar vietos lygmens) supratimas nebūtinai yra vienareikšmiškas. Antra, svarbiausius užsienio politikos ir nacionalinio saugumo sprendimus priima už tai atsakingi valstybès vadovai, todèl itin svarbus yra jų vertinimas. Trečia, sprendimų priemejjai veikia tarptautinès ir vidaus politinių sistemų sankirtoje ir tai ł̇galina arba, atvirkščiai, apriboja sprendimų priemejjų elgseną ${ }^{42}$. Randall'o Schwellerio teigimu, istorinè patirtis rodo, kad valstybès dažnai nepakankamai ivvertina ir subalansuoja savo elgseną kylančiu grèsmių akivaizdoje ${ }^{43}$.

Apibendrinant nagrinėjamą problemą galima išskirti šiuos aktualius veiksnius:

- Tarptautiné sistema sukuria tam tikras galimybes ir apribojimus valstybiu užsienio politikai; pagrindinis veiksnys - valstybių turima galia, o siekis saugumas; tai ypač aktualu mažoms valstybėms;

- galių balanso pokytis tarptautineje sistemoje vertinamas kaip auganti grèsmè saugumui, mažoms valstybėms svarbus - priešiškų ketinimų

\footnotetext{
${ }^{40}$ Snyder G. H., Alliance Politics, Cornell University Press, 1997.

${ }^{41}$ Žr. plačiau, Nye J. S., „Soft Power “, Foreign Policy, No. 80, Autumn 1990, http://faculty.maxwell.syr. edu/rdenever/PPA-730-27/Nye\%201990.pdf, 16022013.

${ }^{42}$ Stephen E. Lobell, “Threat assessment, the state, and foreign policy: a neoclassical realist model”, in: Neoclassical Realism, the State and Foreign Policy, Lobell S., Ripsman N., Talliaferro J.W., eds., 2009, p. 42-74. ${ }^{43}$ Schweller R. L., Unanswered Threats. Political Constraints on the Balance of Power, 2006, p. 10-11.
} 
turinčių kaimynystejje esančių galių stiprejjimas;

- racionali valstybės elgsena augant grèsmėms reikalauja balansuoti, stiprinti aljanso saitus ir tarpusavio priklausomybès ryšius;

- tinkamą valstybės elgseną gali apriboti vidaus veiksniai: valstybės struktūra, jos sprendimų priėmèjų supratimas dèl kylančių grèsmių saugumui pobūdžio ir reikalingų priemonių; pagrindinių veikèjų konsensuso nebuvimas.

Lietuvos narystė NATO ir ES laikoma iš esmès išsprendžianti jos saugumo dilemą tiek „griežtojo“, tiek „švelniojo“ saugumo požiūriu. Lietuva nuolat pabrèžè ir tolesnio transatlantinių santykių plètojimo svarbą. Kaip ir kitoms Europos valstybėms, Lietuvai jie visų pirma reiškia patikimas saugumo garantijas, kurios remiasi Vašingtono sutarties 5-ajame straipsnyje ịtvirtintu kolektyvinès gynybos principu ir galingiausios pasaulio valstybès - JAV - turima galia. Lietuvos narystė NATO ir ES laikoma iš esmès išsprendžianti jos saugumo dilemą tiek "griežtojo“, tiek „švelniojo“ saugumo požiūriu. Lietuva nuolat pabrèžè ir tolesnio transatlantinių santykių plètojimo svarbą. Kaip ir kitoms Europos valstybėms, Lietuvai jie visų pirma reiškia patikimas saugumo garantijas, kurios remiasi Vašingtono sutarties 5-ajame straipsnyje ịtvirtintu kolektyvinès gynybos principu ir galingiausios pasaulio valstybès - JAV - turima galia.

Tačiau globali saugumo aplinka yra nuolat kintanti, dinamiška, atitinkamai kinta ir politikos darbotvarkès. Po 2012 m. ịvykusių prezidento ir Kongreso rinkimų JAV, Lietuvos užsienio politikos formuotojams vienas iš svarbiausių uždavinių - įvertinti galimus JAV politikos pokyčius. Išaugusios grèsmès ir pakitęs jų pobūdis, augančios kitos pasaulio ekonominès galios ir didejjanti tarpusavio ekonominè priklausomybe், vidaus ekonominès-finansinės priežastys ir supratimas, kad Europai nebekyla egzistencinio pobūdžio grèsmių, panašu, JAV strategus privertė iš esmès keisti savo požiūrị.

\section{Augantys „kiti“ ir globali JAV darbotvarkè}

\subsection{Kintantis galios balansas}

Ekonomikos stiprinimas, lyderio vaidmens išlaikymas ir tvaresnès pasaulio tvarkos kūrimas bendradarbiaujant su regioniniais partneriais - taip būtų galima apibūdinti naująją JAV užsienio ir saugumo politikos strategiją. Kartu JAV siekia sumažinti savo galimų karinių intervencijų pasaulyje poreikį, 
skatinant partnerius prisiimti atsakomybę už regioninių saugumo problemų sprendimą.

Jungtinèse Amerikos Valstijose jau kuris laikas vyrauja pasaulinio hegemono vaidmens praradimo nuotaikos ${ }^{44}$. Tokiu JAV buvo tapusios po Šaltojo karo, nors jos tebèra ir artimoje ateityje išliks pasaulio mastu galingiausios. Antai Fareedo Zakaria teigimu, pastaraisiais metais ne tiek silpsta JAV, kiek „auga visi kiti“45. Zbigniewas Brzezinskis ${ }^{46}$ teigia, kad „9/11 šokas“ tapo vienu iš veiksnių, pakirtusių Amerikos pasitikejimą savimi ir pakeitusių jos grèsmių supratimą. Jo nuomone, pasaulis "po Amerikos", t. y. jos galiai tolydžio smunkant, atrodo gerokai nesaugesnis ${ }^{47}$. JAV Nacionalinès žvalgybos tarybos pranešimo „The Global Trends 2025“ duomenimis ${ }^{48}$ tikettinas pasaulio ateities raidos scenarijus - globalios daugiapolès sistemos susiformavimas dèl kylančių naujų galių (Kinijos, Rusijos, Indijos ir kt.), istoriniu vadinamo ekonominès galios poslinkio iš Vakarų i Rytus ir augančios nevalstybinių veikejjų ịtakos. Nauji žaidejjai ị sistemą, prognozuojama, įneš ir naujas žaidimo taisykles. Analitikai, kalbèdami apie pastarojo meto tendencijas, greta globalizmo ịvardija regionalizmo stiprèjimą ir šalia Azijos nurodo Lotynų Amerikos, Artimųjų Rytų, Afrikos regionus, kaip reikalaujančius JAV dėmesio. Identifikuojamos pagrindinès grèsmès - globalios, kaip pvz., masinio (tarp jų ir branduolinio) naikinimo ginklu plètra, terorizmas, ekonomikos ir energetikos klausimai, klimato atšilimas ir pan. Dauguma jų, kaip ir, pvz., kibernetinio saugumo klausimai, atsispindi ir Naujoje NATO Strategineje koncepcijoje ${ }^{49}$.

2010 metais patvirtintoje JAV Nacionalineje saugumo strategijoje taipogi konstatuojamas dèl globalizacijos bei išaugusių grèsmių (dar kartą) besikeičiančio pasaulio vaizdas ${ }^{50}$. Strategijoje konstatuojama, kad beveik dešimtmetị JAV kariavo su „plačiu smurto tinklu“, todèl atėjo metas JAV atsinaujinti sustiprinti savo ekonomiką ir sumažinti biudžeto deficitą, investuoti i švietimą, energetiką, inovacijas, konkurencingumą pasaulineje rinkoje ir iš naujo

\footnotetext{
${ }^{44}$ Žr., pvz., Layne, Ch., „The Waning of US Hegemony - Myth or Reality? A Review Essay“, International Security, vol. 34, no. 1, Summer 2009, p. 147-172.

${ }^{45}$ Žr. plačiau, Zakaria F., The Post-American World, W.W. Norton \& Company, 2008.

${ }^{46}$ Bzrezinski Z., Scowcroft B., America and the World: Conversations on the Future of American Foreign Policy, Basic Books, 2008, p. 3.

${ }^{47}$ Brzezinski Z., „After America“, http://www.foreignpolicy.com/articles/2012/01/03/after_america, 2501 2013.

${ }^{48}$ National Intelligence Council, The Global Trends 2025:A Transformed World, November 2008, http:// www.dni.gov/nic/NIC_2025_project.html, 25012013.

${ }^{49}$ NATO, The 2010 Strategic Concept, http://www.nato.int/cps/en/natolive/official_texts_68580.htm, 03 122012.

${ }^{50}$ National Security Strategy, http://www.whitehouse.gov/sites/default/files/rss_viewer/national_security_strategy.pdf, 03122012.
} 
ivvertinti savo globalų vaidmenị. Dokumente NATO apibūdinamas kaip „išskirtinis saugumo Aljansas" pasaulyje, o santykiai su sąjungininkais Europoje (ypač Jungtine Karalyste, Prancūzija, VFR) įvardijami kaip JAV dalyvavimo pasaulinèje politikoje „kertinis akmuo“. Dar kartą pažymimas įsipareigojimas Vašingtono sutarties 5-ajam straipsniui, tačiau kartu pabrèžiama, kad Aljansas turi būti reformuotas remiantis Naująja NATO strategine koncepcija. Reiškiamas ịsipareigojimas ir partnerystei su stipresne Europos Sąunga siekiant bendrų tikslų, tarp jų skatinti demokratiją ir gerovę Rytų Europos šalyse. Tačiau kovojant su globaliais iššukiais šalia tradicinių sąungininkų ketinama kurti ir naujas partnerystes ir plètoti bendradarbiavimą su kylančiais pagrindiniais itakos centrais - Kinija, Indija, Rusija, o taip pat tampančiomis vis labiau ịtakingesnèmis Brazilija, Pietų Afrika, Indonezija ir kitomis augančiomis valstybèmis. Būtent strateginis Amerikos posūkis ị Azijos ir Ramiojo vandenyno regioną yra vienas iš esminių pirmosios Obamos kadencijos politikos bruožų, kuris, dalies analitikų vertinimu, ir toliau tęsis dèl augančio Kinijos „ekonominio ir geopolitinio žavesio" ${ }^{51}$, nors naujausios visuomenès apklausos vèl rodo transatlantinių santykių reikšmingumą ${ }^{52}$. Strategijoje taip pat akcentuojamas tarptautinių, tokių, kaip JTO, G-20, ir regioninių institucijų vaidmuo kuriant teisingesnę, tvaresnę pasaulio tvarką.

Po 2012 metų JAV Kongreso ir Prezidento rinkimų, pasibaigusių Obamos pergale, analitikai mėgino prognozuoti būsimą šalies užsienio politiką ir įvardyti svarbiausius užsienio politikos uždavinius, laukiančius prezidento antrojoje kadencijoje. Tam tikri politikos pokyčiai tikètini jau vien todèl, kad pasikeitė keli svarbūs Obamos kabineto nariai - paskirti naujieji Valstybės sekretorius Kerry, Gynybos sekretorius Hagelis ir kt. Tačiau dauguma apžvalgininkų ịvardijo labai panašius pagrindinius užsienio politikos uždavinius, kaip ir pirmojoje Prezidento kadencijoje: JAV pajęgų iš Afganistano išvedimas, Iranas, Izraelis, Sirija ${ }^{53}$, taip pat Šiaurès Korejja. Pastarieji klausimai, manoma, dominuos ir transatlantineje darbotvarkèje greta terorizmo, prekybos ir santykių su Rusija klausimų. Naujoji kadencija prezidentui Obamai taip pat suteikia progą iš naujo pažvelgti i santykius su pagrindiniais užsienio partneriais, tarp jų - su Kinijos naujuoju lyderiu Xi Jingping ir su vèl Rusijos prezidentu tapusiu Vladimiru Putinu.

\footnotetext{
${ }^{51}$ Pvz., Engel R., „Top 10 Foreign Policy Issues Facing Obama”, NBC News, 7 November 2012. ${ }^{52}$ The German Marshall Fund of the United States, Transatlantic Trends 2012, http://trends.gmfus.org/ transatlantic-trends-2012-released/, 30122012.

${ }^{53}$ Robinson, D.,„Obama Has Opportunities, Challenges in Second Term“", Voice of America, January, 17, 2013, http://www.voanews.com/content/obama-has-opportunities-challenges-in-second-term/1586094. html, 18012013.
} 


\section{2. „Perkrovos“ pabaiga?}

Bendra darbotvarkè ir visuotinių grèsmių supratimas veikia ir JAV santykių su Rusija konstravimą: pradèti „perkrovą“, siekiant bendradarbiavimo abipusių interesų pagrindu - branduolinio ginklo arsenalo abiejose valstybèse ir pasaulyje sumažinimo; kovos su terorizmu (ypač Afganistane); bendradarbiavimo prekybos srityje. Dialogą ketinama tęsti ir toliau. Nacionalinejje saugumo strategijoje taip pat reiškiamas siekis su šia tarptautinèje sistemoje vèl iškilusia veikejja sukurti „stabilų, esminį, multidimensišką santykị“ siekiant abipusiai naudingų tikslų. Savo ruožtu ir NATO 2012 m. Viršūnių susitikime Čikagoje pareiškè sieksiąs sukurti tikrą strateginę partnerystę su Rusija.

Kaip jau minèta, „perkrovos“ politika, sukèlusi tam tikro nerimo VRE valstybėms, pačiose JAV vertinama nevienareikšmiškai. JAV Council on Foreign Relations vertinimu, „perkrova” padejo pagerinti JAV ir Rusijos santykius, tačiau tarp šalių tebeegzistuoja nesutarimai daugeliu klausimų, ypač dèl JAV priešraketinio gynybos skydo kūrimo Europoje. Steveno Piferio nuomone, „perkrovos“ stadija su santykinai nesunkiais dvišalès darbotvarkès klausimais jau praejo, rinkimai abiejose valstybėse baigèsi, tad išlieka klausimas, ar Rusija pasirengusi iš naujo įsitraukti (ang. re-engage) ir bendradarbiauti branduolinio arsenalo mažinimo ar kompromiso dèl priešraketinès gynybos skydo Europoje klausimais. O pastaruoju metu stebimas ir dvišalių santykių pablogèjimas.

Esama manančiu, kad pagrindinė problema - pačios JAV plaukimas pasroviui (ang. drifting), pastarąji dešimtmetị susitelkus kovai su terorizmu ir neišplètojus globalios vizijos, kai tuo tarpu konkurentai - tarp jų ir i̇ valdžią grižęs Vladimiras Putinas - neslepia savo ambicijų ${ }^{54}$; siekia režimo sutvirtinimo, šalies reindustrializacijos ir "perdetai koncentruojasi“ $\mathfrak{i}$ saugumo reikalus. Vienas iš pavyzdžių - RF Kaliningrado srities militarizacija ${ }^{55}$. Rusijos 2010 metų karinè doktrina NATO pajègumų panaudojimą gynybiniais tikslais ir infrastruktūros plètrą šalyse narèse šalia Rusijos Federacijos sienų ịvardija pirmąja iš pagrindinių karinių grèsmių ${ }^{56}$. Rusijos auganti galia siejama su jos energetiniais ištekliais. Valstybės sekretorè Clinton, baigdama savo kadenciją, pareiškè, kad Rusija siekia plèsti savo politinę ir ekonominę įtaką buvusios SSRS šalyse: „resovietizuoti“ regioną prisidengdama regionine integracija. O Maskva, pasak vicepremjero Dmitrijaus Rogozino, netiki Vašingtono pareiš-

\footnotetext{
${ }^{54}$ Žr. plačiau Engel R., „Top 10 Foreign Policy Issues Facing Obama”, NBC News, 7 November 2012; Opinion, The Huffington Post, 13 November, 2012.

${ }^{55}$ Europos Parlamento rezoliucija dèl Tarybos metinio pranešimo Europos Parlamentui dèl bendros užsienio ir saugumo politikos (12562/2011 - 2012/2050(INI)), 20120912.

${ }^{56}$ Žr. plačiau, RF karinè doktrina, http://www.scrf.gov.ru/documents/18/33.html, 16022013.
} 
kimais, kad priešraketinès gynybos skydas Europoje nėra nukreiptas prieš Rusiją ${ }^{57}$. Todèl, nors Rusija ir nebèra ta egzistencinè grèsmè, kurią kèlè Sovietų Sąjunga, santykių su ja sureguliavimas, ekspertų teigimu, išlieka esminis strateginis uždavinys tiek Jungtinems Valstijoms, tiek ir Europai ${ }^{58}$, kadangi būtent ji išskiriama kaip galinti mesti tiesioginị iššŭkị dabartinei tarptautinei (Rusijos supratimu - JAV dominuojanti) sistemai ${ }^{59}$.

Šios tendencijos ir aplinkybès turètų priversti atkreipti ir Baltijos regiono - pasak Edwardo Lucaso, paties pažeidžiamiausio Europoje regiono valstybių užsienio politikos formuotojų demesį.

\section{Grèsmès Aljansui ir mažėjanti Europos galia}

Pranešime The Global Trends 2025 pažymima, kad NATO pastaruoju metu susiduria su rimtais iššǔkiais dèl gebejjimo prisiimti vis didejjančią, už Aljanso ribų išeinančią atsakomybę ir su mažèjančiais Europos kariniais gebejjimais. Ateityje prognozuojamas tradicinių aljansų silpnejjimas, kartu beveik vienbalsiai sutariama dèl padidejusio nesaugumo XXI amžiuje sklaidos.

Jovitos Pranevičiūtès pastebejjimu, po $2001 \mathrm{~m}$. rugsèjo $11 \mathrm{~d}$. teroristinių išpuolių JAV, Šiaurès Atlanto Aljanso grèsmių sąrašas pradejo plèstis, o kiekviena NATO strategijos peržiūra prideddavo „dar bent vieną ar kelis naujų grèsmių, ǐšūkių ar rizikų apibrěžimus “60. Tačiau ịvairios NATO narès grèsmes Aljansui mato skirtingai - nuo tradicinių iki naujųjų terorizmo, masinių ginklų plètros, energetinių ir kitų grèsmių. Pagal tai ir ịsivaizduojamą NATO vaidmenị ateityje Aljanso šalys skirstytinos ị tris grupes: „reformistès“, „status quo šalininkès" ir "grịžimo ị save propaguotojos“. Pastarajai grupei priskiriamos Lenkija, Čekija ir Baltijos šalys, akcentuojančios realų 5-ojo straipsnio igyvendinimą, pasisakančios už konvencinès ginkluotès planavimą, branduolinio atgrasymo strategiją ir, pasak Pranevičiūtès, niekieno atvirai nepasakomą, tačiau visų suprantamą, vienintelę potencialią grèsmę - Rusiją.

\footnotetext{
${ }^{57}$ „We Don't Take Americans on Trust- Rogozin on AMD“, http://rt.com/politics/rogozin-missile-defenseobama-221/, 18012013.

${ }^{58}$ Michel, L., „Baltic Security: Why the United States (still) cares“, in: Nurick R., Nordenman M., eds., Nordic-Baltic Security in the $21^{\text {st }}$ Century: The Regional Agenda and the Global Role, Atlantic Council September 2011, p. 23 http://www.acus.org/files/publication_pdfs/403/090711_ACUS_NordicBaltic.PDF, 30122012.

${ }^{59}$ The Global Trends 2025, p. 94; t.p. „Navigating Uncertainty. U.S. - Central European Relations 2012“, Center for European Policy Analysis, July 2012, p. 91, http://cepa.org/publications/home.aspx, 25012013. ${ }^{60}$ Pranevičiūtè, J., „Kas ko bijo Šiaurès Atlanto aljanse: naujos ir senos grèsmès“, http://www. delfi.lt/news/ringas/abroad/jpraneviciute-kas-ko-bijo-siaures-atlanto-aljanse-naujos-ir-senosgresmes.d?id=38298463, 18012013 .
} 
Tačiau paradoksas tas, kad potencialių grèsmių sąrašui augant, daugelio sąjungininkių išlaidos gynybai tik mažèjo. Pastarosios ekonominès-finansinès krizès metu dauguma vyriausybių buvo priverstos imtis griežtų taupymo priemonių, taip pat mažinti išlaidas krašto gynybai. O tokios pastarojo meto NATO operacijos, kaip Afganistane ar Libijoje, atskleidè ir tam tikras sąjungininkų silpnybes - jose „sunkiąją“ (t. y. kovinę) užduoties dalį galëjo prisiimti tik nedidelè dalis Aljanso narių. Dar kartą išryškèjo ir vadinamoji „kaštų pasidalinimo" (ang. burden sharing) problema, dèl būtinybès europiečiams investuoti ị savo gynybą vis garsiau ėmè kalbèti oficialūs NATO ir JAV pareigūnai.

Aljanso veikloje dvidešimt aštuonios jo narès dalyvauja keletu būdų, tačiau pagrindiniu laikomas dalyvavimas NATO operacijose ir galimybè dislokuoti ten savo ginkluotąsias pajègas, kaip, pvz., iki 2014 m. tebevykstanti Tarptautinių saugumo paramos pajègų (ISAF) operacija Afganistane (iš viso joje dalyvauja 49 šalys, tarp jų ir Lietuva ${ }^{61}$.

Pagrindinès diskusijos dèl kaštų pasidalijimo Aljanse vyksta būtent dèl ginkluotụjų pajègų dislokavimo NATO operacijose, nes tai ir sudaro didžiąją su NATO naryste susijusių išlaidų dalị. Šiuo metu tik penkios NATO šalys gynybai skiria sutartus 2 proc. BVP šalies gynybai, o bendrai Europos šalių skiriamos išlaidos per pastarajji dešimtmetị sumažèjo beveik 15 procentų. Be to, vertinant šalių gynybos biudžeto rodiklius, atsižvelgiama ne tik ị konkrečius skaičius, bet ir personalui ir ginkluotès atnaujinimui skiriamų lěšų proporcijas. Pastaraisiais metais bendras NATO šalių vidurkis (išskyrus JAV) ̨ૃrangai įsigyti siekè tik 16,7 proc. gynybos išlaidų (atskirose narèse - mažiau nei 10 procentų), didžioji išlaidų dalis teko personalo atlyginimams. Tai kelia abejonių dèl sąungininkių gebėjimų atremti tradicines ir naujas grèsmes, dalyvauti naujose operacijose. Lietuva yra atsidūrusi priešpaskutinèje vietoje pagal savo gynybai skiriamų išlaidų dydị (1 lent. ). Tarptautinès ekspertų grupès vertinimu, jei išliks dabartinès tendencijos, Lietuva ateityje gali nebepajėgti vykdyti savo narystės Aljanse įsipareigojimų ${ }^{62}$.

\footnotetext{
${ }^{61}$ NATO, International Security Assistance Force (ISAF): Key Facts and Figures, http://www.nato.int/ isaf/docu/epub/pdf/placemat.pdf, 13092012.

${ }^{62}$ Kaljurand R., Neretnieks K., Ljung B., Tupay J., „Developments in the Security Environment of the Baltic Sea Region up to 2020", September 2012, http://www.icds.ee/fileadmin/failid/Developments $\% 20$ in $\% 20$ the $\% 20$ Security $\% 20$ Environment $\% 20$ of $\% 20$ the $\% 20$ Baltic $\% 20$ Sea $\% 20$ Region $\% 20$ up $\% 20$ to $\% 20$ 2020.pdf, 05012013 .
} 
1 lentelè. NATO šalių gynybos išlaidos ${ }^{63}$

\begin{tabular}{|c|c|c|c|}
\hline Šalis & $\begin{array}{c}\text { Gynybos išlaidos } \\
2005-2009 \mathrm{~m} . \\
\text { (vidurkis, proc. } \\
\text { nuo BVP) }\end{array}$ & $\begin{array}{c}\text { Gynybos išlaidos } \\
2009 \text { m. } \\
\text { (proc. nuo BVP) }\end{array}$ & $\begin{array}{l}\text { Gynybos išlaidos } \\
2011 \mathrm{~m} . \\
\text { (proc. nuo BVP) }\end{array}$ \\
\hline JAV & 4,5 & 5,4 & 4,8 \\
\hline Turkija & 3,2 & 2,1 & 1,9 \\
\hline Graikija & 2,9 & 3,2 & 2,1 \\
\hline Jungtinè Karalystè & 2,3 & 2,7 & 2,6 \\
\hline Prancūzija & 2,3 & 2,1 & 1,9 \\
\hline Bulgarija & 2,2 & 1,9 & 1,4 \\
\hline Norvegija & 1,9 & 1,7 & 1,5 \\
\hline Lenkija & 1,7 & 1,7 & 1,7 \\
\hline Estija & 1,6 & 1,8 & 1,7 \\
\hline Slovakija & 1,6 & 1,5 & 1,1 \\
\hline Italija & 1,6 & 1,4 & 1,4 \\
\hline Portugalija & 1,5 & 1,6 & 1,5 \\
\hline Slovènija & 1,5 & 1,6 & 1,3 \\
\hline Čekija & 1,5 & 1,6 & 1,1 \\
\hline Kroatija & n.d. & 1,6 & 1,5 \\
\hline Albanija & n.d. & 1,5 & 1,5 \\
\hline Nyderlandai & 1,5 & 1,5 & 1,3 \\
\hline Danija & 1,4 & 1,4 & 1,4 \\
\hline Rumunija & n.d. & 1,4 & 1,3 \\
\hline Latvija & 1,4 & 1,2 & 1,0 \\
\hline Kanada & 1,3 & 1,4 & 1,4 \\
\hline Vokietija & 1,3 & 1,4 & 1,4 \\
\hline Vengrija & 1,3 & 1,2 & 1,0 \\
\hline Ispanija & 1,2 & 1,2 & 0,9 \\
\hline Belgija & 1,1 & 1,2 & 1,1 \\
\hline Lietuva & 1,1 & 1,1 & 0,8 \\
\hline Liuksemburgas & 0,5 & 0,4 & 0,5 \\
\hline
\end{tabular}

Oficialiais dokumentais Lietuva ne kartą yra patvirtinusi įsipareigojimą atitinkamai finansuoti krašto apsaugą, t. y. 2001 m., 2004 m. politinių partijų susitarimais, Seimo 2004 m. gegužès 1 d. rezoliucija, kuriais jau 2005-2008 m. krašto apsaugai

\footnotetext{
${ }^{63}$ Sudaryta autorès, remiantis $2012 \mathrm{~m}$. NATO pranešimu apie šalių narių gynybos išlaidas, Financial and Economic Data Relating to NATO Defence, April 13, 2012, http://www.nato.int/nato_static/assets/pdf/ pdf_2012_04/20120413_PR_CP_2012_047_rev1.pdf, 14092012.
} 
žadèta skirti ne mažiau kaip 2 proc. BVP, pagaliau ir naujausias - $2012 \mathrm{~m}$. gegužès mèn. susitarimas. Tačiau iki šiol nẻ karto šis rodiklis nebuvo pasiektas, kol kas nėra sutarta, ir kaip pastarasis susitarimas bus igyvendinamas. Nacionalinëje saugumo strategijoje nepakankamas gynybos srities finansavimas laikomas vienu iš vidaus rizikos veiksnių, galinčiu turèti didelès ịtakos Lietuvos Respublikos nacionaliniam saugumui.

Atsisveikinimo kalboje Briuselyje $2011 \mathrm{~m}$. birželio $10 \mathrm{~d}$. JAV gynybos sekretorius Robertas Gatesas nedviprasmiškai perspejo sąungininkus Europoje, kad transatlantinio Aljanso laukia „miglota, jei ne niūri ateitis“ („a dim, if not dismal future for the transatlantic alliance"), jei NATO valstybès narès rimtai neịsipareigos padidinti lěšu gynybai ir svariau dalyvauti NATO operacijose. JAV dalis NATO gynybos biudžete po Šaltojo karo pabaigos padidèjo nuo 50 proc. iki daugiau nei 70 proc., o ekonomiškai stiprių Europos valstybių lěšos gynybai nuolat mažẻjo (žr. 2 pav.), dalis jų specializuojasi „švelniosiose“ užduotyse.
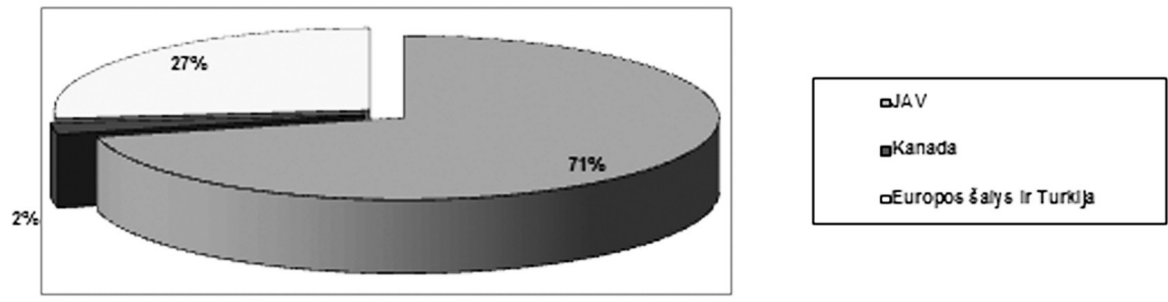

\section{1 pav. NATO šalių bendrosios gynybai skiriamos lèšos}

Pasak Gateso, Europa negali tikètis, kad JAV mokesčių mokètojai visada mokès už jos saugumą: jei nepasikeis dabartinès Europos gynybinių galių smukimo tendencijos, būsimoji JAV politikos lyderių karta, užaugusi po Šaltojo karo, gali „nebematyti Amerikos investicijų i NATO prasmès“64.

JAV perspejimai Europai, susiję su pačios Amerikos ketinimais žymiai riboti savo karines išlaidas, reiškiami aštrių politinių debatų dẻl bendro šalies biudžeto deficito sumažinimo kontekste. $2011 \mathrm{~m}$. JAV gynybos išlaidos sieke beveik 700 mlrd. JAV dolerių, o pats gynybos biudžetas siekė $530 \mathrm{mlrd}$. JAV dolerių, $160 \mathrm{mlrd}$. JAV dolerių buvo papildomai skirta karų Afganistane ir Irake reikmėms. 2011 m. JAV ịsigaliojusiame Biudžeto kontrolès akte 2013-2021 m. numatyta sumažinti JAV biudžeto deficitą 1,5 trilijono dolerių, ịtraukiant

\footnotetext{
${ }^{64}$ Gardiner N., ,America's European allies must heed US Defence Secretary Robert Gates’ warning on the future of NATO", The Telegraph, June 10, 2011, http://blogs.telegraph.co.uk/news/nilegardiner/100091737/america\%E2\%80\%99s-european-allies-mustheed-us-defence-secretary-robert-gates \%E2\%80\%99-warning-on-the-future-of-nato/, 30122012.
} 
ir karinio biudžeto išlaidų mažinimą. Šio straipsnio rengimo metu dar nebuvo žinoma, dèl kokių tolesnių biudžeto mažinimo priemonių sutars demokratų ir respublikonų lyderiai, tačiau dabartinè 16 trilijonų JAV dolerių siekianti federalinio biudžeto skola (viršijanti JAV BVP ir atitinkanti 16 Marshallo planų) Amerikos politinio elito atstovų vertinama kaip „nacionaliné saugumo krizė“ ekonominio saugumo prasme ${ }^{65}$. Tiesa, Amerikos galia net ir blogiausio scenarijaus - nusavinimo (ang. sequestration) atveju išliks pakankamai didelè: planuojamas JAV karinis biudžetas 2013 metais sieks 38-40 proc. bendro pasaulinio karinio biudžeto, tuo tarpu artimiausių potencialių varžovių rodikliai gerokai mažesni: Kinijos $-8,2$ proc., Rusijos - 3,9 proc.

$2012 \mathrm{~m}$. paskelbtose JAV Gynybos departamento strateginèse gairèse nurodoma, kad JAV užsienio ir saugumo politikos prioritetu laikoma nebe Europa, o Azija - Ramiojo vandenyno regionas ir Artimieji Rytai ${ }^{66}$. Tai reiškia ir strategiškai kitokį JAV ginkluotųjų pajègų - karinių bazių ir su jomis susijusios infrastruktūros perdislokavimą pasaulyje. Pavyzdžiui, iki 2015 m. Europoje dislokuotų karių skaičių ketinama sumažinti iki 70 tūkstančių karių (plg. Šaltojo karo metais - apie 300 tūkst. JAV karių) ${ }^{67}$. Taigi, tiek tolesnis JAV gynybos išlaidų sumažinimas 2013-2021 m., tiek identifikuojamų pagrindinių grèsmių arealo persikèlimas ị kitus žemynus reiškia viena: sąjungininkai Europoje privalo patys prisiimti daugiau atsakomybės už savo saugumą, plètoti gynybinius pajègumus, remdamiesi naująja NATO Strategine koncepcija, mažinti atotrūkị nuo JAV siekiant bendro tikslo - „NATO pajègos 2020“. Visos šalys raginamos daugiau prisidèti ir prie išmaniosios gynybos, kurios vienu iš sèkmingų pavyzdžių 2012 m. Čikagos NATO Viršūnių susitikime buvo įvardyta ir NATO oro erdvès patruliavimo misija Baltijos šalyse, pratęsta iki 2018 metų, kol bus surastas ilgalaikis sprendimas.

\section{Iššūkiai Europai: kartu ar atskirai?}

Pirmininkavimo Europos Sąungos Tarybai (toliau - EST) kontekstas bent jau viešojoje erdveje padejo ịtvirtinti ne tik regioninę (VRE ar Šiaurès

\footnotetext{
${ }^{65}$ Singer P. W., ,Separating Sequestration Facts from Fiction: Sequestration and What It Would Do for American Military Power", Time Magazine, http://www.brookings.edu/research/articles/2012/09/23sequestration-defense-singer, 30122012.

${ }^{66}$ US Department of Defence, Sustaining US Global Leadership:Priorities for 21st Century Defence, January 2012, http://www.defense.gov/news/Defense_Strategic_Guidance.pdf, 14092012.

${ }^{67}$ Vandiver J., ,Pentagon lays out significant cuts to U.S. Forces in Europe“, Stars and Stripes, February 12, 2012, http://www.stripes.com/news/pentagon-lays-out-significant-cuts-to-u-s-forces-in-europe-1.168861, 18092012 .
} 
Baltijos), bet ir europietiškąą Lietuvos tapatybę. O Europai šiandien kylantis iššūkis: ịvertinti pakitusị pasaulio geopolitinị paveikslą ir tai, kaip Europa save mato jame. Pastaruoju laikotarpiu ES, panašu, kur kas daugiau dėmesio sulaukè euro zonos, ekonominès-finansinès krizès klausimai, Viduržemio jūros regiono problemos. Europos Komisijos pirmininko José Manuelio Barroso nuomone, globalių iššūkių akivaizdoje reikalinga gilesnė ekonominė ir finansinė integracija, t. y. Europos valstybių federacija ${ }^{68}$. Su tuo, panašu, nesutinka bent jau Jungtinè Karalystė, suvereniteto ir federalizmo balanso klausimas, ypač užsienio ir saugumo politikos srityje, aktualus ir kitoms valstybems.

Lisabonos sutartimi ES ịsipareigojo siekti bendros Europos užsienio ir saugumo politikos. Isteigta ES vyriausiojo iggaliotinio bendrajai užsienio ir saugumo politikai pareigybè, sukurta ir atskira Europos Išorès Veiksmų Tarny$\mathrm{ba}^{69}$. Pusę praejjusio amžiaus akcentavusi ekonominę integraciją, Europa siekia vis aiškiau apsibrežti save ir kaip globalų politinį veikejją su aiškesne išorine tapatybe. Europa deklaruoja, kad JAV jai esanti pagrindinè strateginè partne$\mathrm{re}^{70}$, su kuria norima bendradarbiauti ịvairiose srityse - nuo taikos, stabilumo ir demokratijos plètros pasaulyje iki kovos su visuotiniais iššǔkiais, tačiau iki šiol akivaizdesnè pažanga buvusi plètojant transatlantinius ekonominius santykius. ES ir JAV prekybos ir investicijų apimtis yra didžiausia pasaulyje - apie 31 proc. bendros prekybos apimties, 49 proc. bendro pasaulio $B V P^{71}$. Esama sričiu, kur transatlantinis bendradarbiavimas nèra toks sklandus, kaip, pvz., JAV iki šiol nesuteikia bevizio režimo kai kurioms ES valstybèms, kaip Lenkija ar Bulgarija. Ivvertinant pastarojo meto globalius pokyčius, ES pletrą ir kitus veiksnius, Europoje yra pasisakančių (pvz., Švedija ir kt.) dèl naujos Europos Sąjungos saugumo strategijos poreikio (paskutinis dokumentas šioje srityje priimtas dar 2003 metais), kita vertus, nuogąstaujama, kad taip tik gali būti atverta savotiška Pandoros skrynia.

Saugumo ir gynybos srityje gan ilgai buvo siekiama vengti NATO dubliavimo, Aljansas ir toliau išlieka pagrindinis Europos saugumo garantas. ES

\footnotetext{
${ }^{68}$ Barroso J. M., State of the Union 2012, http://ec.europa.eu/commission_2010-2014/president/pdf/brochure_en.pdf, 01032013.

${ }^{69}$ Plačíau žr. Šešelgytė M., Lelevičiūtè I., „Lisabonos sutarties poveikis ES bendrai saugumo ir gynybos politikai“, Lietuvos metiné strategine apžvalga 2010-2011, p. 95-125.

${ }^{70}$ Scammell R., „Is Obama's Re-election Good for Europe“, http://www.eui.eu/News/2012/11-07-IsObamasre-electiongoodforEurope.aspx, 18012013.

${ }^{71}$ EU External Action Service, United States of America, http://eeas.europa.eu/us/index_en.htm, 1801 2013..
} 
ir NATO plètojo transatlantinị bendradarbiavimą krizių valdymo ${ }^{72}$, keitimosi informacija ir kitose srityse. Tačiau Europos Vadovų Taryba 2012 metų pabaigoje pakviete ES vyriausiąją igaliotinę parengti ir pateikti priemonių planą, kaip sustiprinti Bendrąją saugumo ir gynybos politiką (BSGP) iki $2013 \mathrm{~m}^{.73}$ Visgi, iki šiol nèra galutinai igyvendinti BSGP (ESGP) užsibrěžti tikslai, kuriuos buvo numatyta igyvendinti iki $2003 \mathrm{~m}$., vèliau - iki $2010 \mathrm{~m}$. (Headline Goal 2010 ${ }^{74}$. Apžvalgininkų nuomone, ir šioje srityje buvo stokojama sutarimo tarp skirtingų veikejų, trūko atitinkamų pajėgumų. Kiekvienos ES valstybès ịsitraukimas ị karines operacijas ir toliau išlieka politinès valios reikalu, o ES kovinès grupès iki šiol niekada nebuvo panaudotos.

Nors rinkimų kampanijos JAV metu Europos tema beveik nefigūravo, Obamos perrinkimas JAV prezidentu Europoje apskritai buvo sutiktas palankiai $^{75}$. Tačiau prisiminus Obamos žodžius, kad JAV nebenori būti Europos patrone, o siekia būti jos partnere, European Council on Foreign Relations (ECFR) ekspertų nuomone, tai kartu reiškia, kad Europai „atėjo metas suaugti“ ir pačiai imtis spręsti tiek santykių su Rusija ar Rytų kaimynemis klausimus, tiek įsitraukti ir ị Sirijos, Irano, Artimųjų Rytų ir kitų klausimų sprendimą ${ }^{76}$. Kaip studijoje apie JAV ir ES santykius teigia Jeremy Shapiro ir Nick Witney ${ }^{77}$, grèsmè transatlantiniam ryšiui kyla ne dèl Amerikos globalios strategijos, bet dèl to, kad pati Europa dar neįsisąmonino, kaip keičiasi pasaulis ir kaip dèl to turètų pasikeisti transatlantinis ryšys ${ }^{78}$. Dabartinis Europos santykis su JAV apibūdintas kaip konfliktiškas, susidedantis iš daugelio tapatybių: Europos valstybių dvišalių santykių su JAV (kuriuos dauguma, pradedant Jungtine Karalyste, Nyderlandais ir baigiant VRE, mano, kad jie yra ypatingi); gynybos santykių per NATO ir besiplètojančių ES santykių su JAV. Stefanas Lehne'as atvirai įvardija,

${ }^{72}$ EU-NATO Declaration on ESDP, http://www.consilium.europa.eu/uedocs/cmsUpload/73803\%20 -\%20Solana\%20-\%20Permanent\%20arrangements\%20+\%20NATO\%20declaration.pdf; EU-NATO: The Framework for Permanent Relations and Berlin Plus, http://www.consilium.europa.eu/uedocs/cmsUpload/03-11-11\%20Berlin\%20Plus\%20press\%20note\%20BL.pdf, 29122012.

${ }^{73}$ Frontini A., ,A battle against decline? EU defence after the European Council“, 17 December 2012, http://www.epc.eu/pub_details.php?cat_id=4\&pub_id=3198, 23012013.

${ }^{74}$ Greco E. et al, eds., "EU crisis management institutions and capabilities in the making", IAI, November 2010, http://www.iai.it/pdf/Quaderni/Quaderni_E_19.pdf; European Parliament, The impact of the financial crisis on European defence, April, 2011,

http://www.europarl.europa.eu/document/activities/cont/201106/20110623ATT22404/20110623ATT2240 4EN.pdf, 10032013.

${ }^{75}$ Thompson M., „European Leaders: Let's get European Economy Moving“, CNN, http://money.cnn. com/2012/11/07/news/economy/europe-election-economy/index.html, 23012013.

${ }^{76}$ Bechev D. et al „Time to Grow-up: what Obama's re-election means for Europe“, http://ecfr.eu/content/ entry/time_to_grow_up_what_obamas_re_election_means_for_europe, 18012013.

${ }^{77}$ Shapiro J., Witney N., Towards a Post-American Europe: A Power Audit of EU-US Relations, ECFR, http://pasos.org/wp-content/archive/ECFR_EUUSrelations.pdf, 29122012.

${ }^{78}$ Ten pat, p. 8. 
kad stebètojo iš šalies akimis vienbalsiai sprendimus užsienio politikos srityje priimantis 28 valstybių narių blokas ${ }^{79}$ (kur visos šalys formaliai turi vienodą svorị priimant sprendimus) visgi turi tris pagrindinius veikejjus - VFR, Prancūziją, Didžiąją Britaniją, nuo kurių laikysenos didele dalimi priklauso ir visos ES pozicija. Autorių nuomone, užuot tebegyvenusi mitais (pvz., apie labiau „europietiškas" ar labiau transatlantinị ryši akcentuojančias valstybes), ES turètų gebèti formuoti ir vykdyti bendrą užsienio politiką.

Europos nenoras ar negebẻjimas kalbèti vienu balsu lig šiol kliudè jai veiksmingai kalbètis ne tik su JAV, bet ir su kitomis galingosiomis valstybėmis - Kinija ir Rusija. Shapiro ir Witney nuomone, Europos valstybėms diskusijos ES viduje apie skirtingas saugumo sampratas skirtingose žemyno dalyse turètų tapti norma, nes tik taip gali būti ịveiktas pasitikèjimo trūkumas tarp senųjų ir vis dar naujosiomis laikomų ES narių. Jos turi imtis spręsti ir saugumo klausimus užuot laukus Vašingtono sprendimo dèl, pvz., didesnio NATO matomumo VRE regione reikalingumo ar jų priklausomybės nuo Rusijos energetikos sektoriuje ${ }^{80}$. ES raginama transatlantiniam ryšiui suteikti tokias savybes: atsakomybés prisièmimą saugumo klausimais; siekti susitarimų - tam reikalinga ne tik užsienio politikos problemų analizè, bet ir konkrečios iniciatyvos prie derybų stalo; veikti remiantis argumentais; rinktis „chorą", o ne „solo“ partijas. Viena iš pagrindinių ịvardijamų priežasčių, iki šiol trukdžiusių Europai parodyti savo bendrą balsą ir tapti reikšmingu tarptautiniu veikèju - politinès valios ir strateginio požiūrio stoka.

Statkus ir Paulauskas pastebejo, kad iki šiol ir Lietuvos politinis elitas vadovavosi (klaidinga) prielaida, kad BUSP stiprèjimas (be kurios ES neịsivaizduojama kaip politine sąjunga) gali pakenkti transatlantiniam ryšiui ir argumentuoja, kad Lietuva kaip tik yra būtent šio kolektyvinio subjekto - Europos - tapatybės dalis ${ }^{81}$, taigi, gali daryti ịtaką jo politikai. Lietuva savo pirmininkavimo EST darbotvarkèje vienu iš svarbiausių prioritetų ịvardijo Rytų partnerystę - kaip prielaidą sukurti saugesnę, demokratiškesnę erdvę ES kaimynystėje ir taip prisidèti prie ES saugumo didinimo. Atsižvelgiant ị dabartinę institucinę sąrangą, Lietuvos galimybės daryti ịtaką bendrai ES užsienio ir saugumo politikai yra ribotos, tačiau diskusijoms ji gali pateikti savo argumentų ir idejų. Lietuva gali prisidèti ir prie derybų dèl laisvos prekybos sutarties su JAV (ang. Transatlantic Trade and Investment Partnership) sèkmingos baigties. Dabartinių ekonominių iššūkių abiejose Atlanto pusèse fone ši sutartis, tikimasi, ne tik atneš abipusę naudą siekiant ekonominio atsigavimo, bet ir suteiks papil-

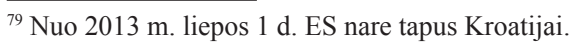

80 Ten pat, p. 17.

${ }^{81}$ Statkus N., Paulauskas K., Tarp geopolitikos ir postmoderno: kur link sukti Lietuvos užsienio politikai?, 2008, p. 51.
} 
domą postūmị transatlantinių ryšių plètrai. Tai aktualu ir Lietuvai sprendžiant ekonominio ir socialinio saugumo klausimus: 2011 metais 33 proc. Lietuvos gyventojų buvo atsidūrę ant skurdo ar socialinès atskirties ribos, tarptautiniai tyrimai rodo augantį Lietuvos gyventojų nusivylimą demokratija, rinkos ekonomika ir šalies politikos būkle ${ }^{82}$.

\section{Išvados}

Šiame straipsnyje dar kartą sugrižta prie transatlantinių santykių ir Lietuvos saugumo klausimų ir argumentuota, kad jie tebèra aktualūs.

Mažujų valstybių teorija teigia, kad dèl ribotos galios saugumo klausimai mažosioms valstybėms yra ypč svarbūs. Pirminiai veiksniai, darantys įtaką valstybès užsienio politikai - sisteminiai struktūriniai veiksniai; ịprastai mažųjų valstybių elgsena apibūdinama kaip „prisitaikymas prie realybės“. Remiantis teorija, mažosios valstybès, siekdamos saugumo, iprastai renkasi balansavimo strategiją; globaliame pasaulyje akcentuojama „švelnioji galia“. Augant išorès grèsmèms, valstybè turètų stiprinti aljanso saitus ir didinti tarpusavio priklausomybę; konstruktyvistiniu požiūriu - puoselèti bendrą tapatybę. Pabrèžiama, kad mažos (silpnos) valstybès negali prarasti budrumo saugumo klausimuose ar mėgautis vien didžiosios galios teikiama apsauga.

Lietuva, tapusi NATO ir ES nare, laikoma iš esmès išsprendusi savo saugumo dilemą. Jos užsienio politika pasižymi ir kitais mažųjų valstybių užsienio politikai būdingais bruožais: dèmesiu artimiausiam geografiniam regionui (pvz., Rytų kaimynystè), tarptautinių institucijų ir moralès normų, vertybių akcentavimu. Tačiau pasigendama ekonominių - prekybos partnerių diversifikacijos (pastaraisiais metais ypač išaugo priklausomybė nuo vieno tiekejjo energetikos srityje), nepaisant viešajam diskursui būdingos užsienio politikos klausimų „saugumizacijos", skiriami ištekliai krašto apsaugai - vieni iš pačių mažiausių Aljanse. Neoklasikiniai realistai tokią neracionalią grèsmių balanso teorijos požiūriu valstybės elgseną aiškina ịsiterpiančiais vidaus veiksniais, t.y. valstybès institucinè sandara ir jos sprendimų prièméjai. Lietuva yra parlamentinè respublika (su tam tikrais prezidentizmo bruožais), jos valstybès vadovas sprendžia pagrindinius užsienio politikos klausimus ir kartu su vyriusybe vykdo užsienio politiką. Remiantis neoklasikinio realizmo teorija, būtent sprendimų prièmejju supratimas apie kylančius iššūkius saugumui, gebejjimas mobilizuoti raktinių

\footnotetext{
${ }^{82}$ Confidence in Democracy and Capitalism Wanes in Former Soviet Union, December 5, 2011, http:// www.pewglobal.org/2011/12/05/confidence-in-democracy-and-capitalism-wanes-in-former-soviet-union/, 29122012
} 
socialinių veikejjų paramą yra pagrindiniai veiksniai, lemiantys (tinkamus) saugumo problemų sprendimo būdus.

Mažujų valstybių užsienio politikos formuotojams itin svarbus veiksnys tinkamas tarptautinès sistemos pokyčių vertinimas. Pastaruoju metu dẻl augančių regioninių galių stebimas poslinkis nuo vienpolio ị daugiapolị pasauli, akcentuojama išaugusi ekonominè tarpusavio priklausomybè ir globalios grèsmès. Atitinkamai keičiasi ir strateginio Lietuvos (ir Europos) partnerio - Jungtinių Amerikos Valstijų užsienio ir saugumo politika („posūkis ị Aziją"). Nors deklaruojami išliekantys JAV ịsipareigojimai Šiaurès Atlanto Aljansui ir tradiciniams sąjungininkams Europoje, pastarieji raginami patys prisiimti daugiau atsakomybès už regiono saugumo problemų sprendimą. JAV gynybos išlaidų mažinimas ir strategiškai kitoks jos gynybinių pajègumų perdislokavimas pasaulyje turètų paskatinti Europą investuoti ị savo gynybinių pajëgumų stiprinimą. Bendrosios ES saugumo ir gynybos politikos stiprinimas bus svarstomas aukščiausiu lygiu jau 2013 metų pabaigoje.

Lietuva dèl savo geopolitinès situacijos yra ypač suinteresuota transatlantinių santykių gyvybingumu. Jiems šiandien yra iškilę bent jau du iššūkiai: vieningesnio Europos požiūrio ị savo vaidmenị pasaulyje poreikis ir ekonominiai-finansiniai iššūkiai abiejose Atlanto pusèse. Dèl susiformavusios institucinès sandaros Lietuvos galimybės daryti ịtaką ES bendrajai užsienio ir saugumo politikai yra ribotos, tačiau Lietuva pasirengusi prisideti prie regiono saugumo stiprinimo per Rytų partnerystę. Laisvosios prekybos sutarties su JAV perspektyva atveria galimybes abipusiam ekonominiam atsigavimui ir socialiniųekonominių transatlantinių ryšių stiprinimui.

Sekant Kopenhagos mokyklos autoriais, saugumas kyla ne tik iš galios sutelkimo, bet ir iš bendros tapatybès kūrimo. Tyrimai atskleidžia, kad ir šia prasme Lietuvos integracija ị transatlantinę saugumo bendruomenę - dar neužbaigtas klausimas.

Apibendrinant, šiame straipsnyje siekėme ịrodyti, kad transatlantinių santykiụ ir saugumo klausimai Lietuvai tebèra svarbūs. Jų sprendimai galètų būti tokie:

- tapti patikima, lojalia Aljanso partnere ne tik įsipareigojant bendrai Aljanso politikai ir strategijai, bet ir atitinkamai investuojant i gynybinių pajègumų plètrą;

- toliau didinti euroatlantinę integraciją ekonominèje ir socialinëje srityse; stiprinti tarpusavio priklausomybę atitinkamai perorientuojant ir diversifikuojant savo ekonominius ir prekybinius ryšius; skatinti žmogiškujų ryšių plètrą;

- valstybès viduje toliau stiprinti Vakarų demokratines vertybes ir institucijas; 
- artèjant Lietuvos narystės euroatlantinèse struktūrose dešimtmečiui ir atsižvelgiant ị išorèje vykstančius procesus, viešojoje sferoje galètų îvykti diskusija apie kintančią tarptautinę situaciją, Lietuvos vietą ir vaidmenị pasaulyje, jos grèsmių supratimą, kartu su partneriais abiejose Atlanto pusèse ieškant bendrų saugumo sprendimų.

2012 m. rugsèjis - 2013 m. kovas 